短報

\section{ジクロルベンジジンの尿中代謝物と その変異原性}

Urinary Metabolites of 3, 3'-Dichlorobenzidine and Their Mutagenicity

ベンジジン $(\mathrm{BZ})$ の生体内運命については近年いくつ かの新しい知見が得られている。 しかし特化則第 1 類に あげられている BZ 類似物質の代謝が BZ に比しどのよ らな異同を示永ついては十分明らかにされていな い. Sciarini ${ }^{11}$ はイヌ腹腔内に, Kellner ${ }^{2)}$ はラットイ ヌ, サルの静脈内にジクロルベンジジン $\left(3,3^{\prime}\right.$-dichlorobenzidine, 以下 $\mathrm{DCBZ}$ と略）㕛投与乙尿中に DCBZ それ自身をみいだしているが，代謝物はいずれの場合も みいだされていない，著者は DCBZ を経口，経気道， 経皮の 3 通りの方法でラットに投与し，并の尿中に DCBZ の代謝物として 3, 3'-dichloro-N-acetylbenzidine (N-AcDCBZ), 3, 3'-dichloro-N, N'-diacetylbenzidine (NN'-AcDCBZ) をみいだした。ついで合成されたこれ らの代謝物についてその変異原性を，サルモネラ菌によ る復帰恋異試験了により検討し若干の知見を得たので報 告する。

\section{突験初料および实験方法}

検体：DCBZ は和光純渻特級試薬を使用した。 N-Ac DCBZ, NN'-AcDCBZ 深 DCBZ と無水酶酸との反応に

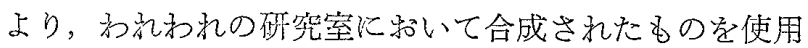
した。

動物：生後約 15 週龄体重注涪 $400 \mathrm{~g}$ の SD 系雄ラッ 卜を使用した。ラット 20 匹究 1 群 5 匹計 4 群炕分から， 第 1 群には DCBZ をアラビアゴム懸濁液として1匹出

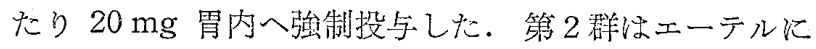
よる軽麻酔下に前頸部皮䖉切開を行ない, $10 \mathrm{mg}$ の

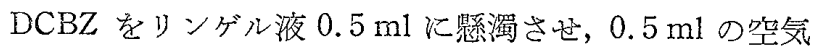
とともに気管内へ注入した。第 3 碓は $100 \mathrm{mg}$ のCBZ と等量のワセリンを混合し，約 $5 \mathrm{~cm}^{2}$ のリント布に塗布 したものを剩毛ラット左右側腹部へ 1 箇所ずつ貼 付し た。第4 群は DCBZ の投与を行なわない刘照とした。

尿試料の分析：上記いずれの場合も投与後 24 時閒中 の尿を 1 匹ごと採取し $\mathrm{pH}$ を 7 亿修正した後エーテル で抽出を行ない，抽出物についてガスクロマトグラフィ 一 (GC), 高速液体クロマトグラフィー (HPLC) Kよる 成分の分析を実施した。

変異原性試験：DCBZ, N-AcDCBZ, $\mathrm{NN}^{\prime}-\mathrm{AcDCBZ}$,
Table 1. Urinary metabolites of $3,3^{\prime}$-dichlorobenzidine and mutagenic activity of the urine.

\begin{tabular}{|c|c|c|c|c|c|c|c|}
\hline \multirow[t]{2}{*}{ Group } & \multirow{2}{*}{$\begin{array}{l}\text { Remininistation } \\
\text { reite and ioso } \\
\text { pex rat }\end{array}$} & \multirow{2}{*}{ 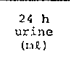 } & \multirow{2}{*}{ 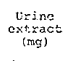 } & \multicolumn{3}{|c|}{ 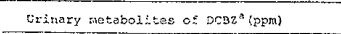 } & \multirow{2}{*}{$\begin{array}{l}\text { putagesic } \\
\text { activity } \\
\text { wrine }\end{array}$} \\
\hline & & & & $D C B 2$ & $\therefore-A C D C A z^{3}$ & $\therefore, y^{\prime}-\mathrm{i} \subset \mathrm{CCB} z^{2}$ & \\
\hline 3 & par mouth, $20 \mathrm{mg}$ & $61 \pm 3^{d}$ & $3 \pm 1^{e}$ & $\begin{array}{l}0.21 \pm 0.06= \\
0.03 \div 0.029\end{array}$ & $\begin{array}{l}3.39=0.10 \\
2.050\end{array}$ & $\begin{array}{l}1.13 \pm 0.49 \\
(0.03 \pm 0.02)\end{array}$ & $5 / 5^{9}$ \\
\hline 2 & per trachen, $20 \mathrm{mss}$ & $41 \pm 8$ & $3 \pm 3$ & $\begin{array}{l}0.20 \\
(0.05\end{array}$ & $0.71 \div 0.81$ & $\begin{aligned} 2.53 & \pm 0.89 \\
(0.07 \pm 0.01) & \pm 0.01)\end{aligned}$ & $5 / 5$ \\
\hline 3 & pork skin, $200 \mathrm{mg}$ & $35 \div 8$ & $4 \div 1$ & $\mathrm{No}^{\mathrm{h}}$ & $:: 0$ & $\begin{aligned} 2.34 \\
(2.03 \pm 0.65 \\
\pm 0.03\}\end{aligned}$ & $0 / 5$ \\
\hline 4 & con: & $31 \pm 4$ & $3=2$ & mo & : & $: D$ & $0 / 5$ \\
\hline
\end{tabular}

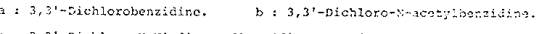

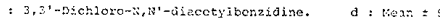

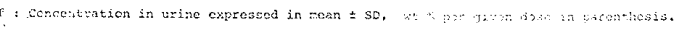

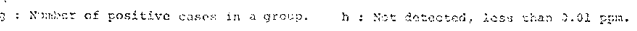

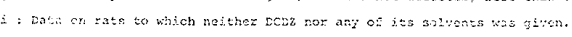

Table 2. Mutagenicity of 3,3'-dichlorobenzidine and its metabolites.

\begin{tabular}{|c|c|c|c|c|c|}
\hline \multirow{2}{*}{ Sartple } & \multirow{2}{*}{$\begin{array}{c}\text { Dose } \\
\text { (Mg/plate) }\end{array}$} & \multicolumn{4}{|c|}{ 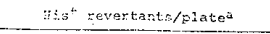 } \\
\hline & & $\begin{array}{l}\min _{205} 8 \\
-89\end{array}$ & $\begin{array}{l}2 \times 99 \\
75: 3\end{array}$ & $\begin{array}{l}\mathrm{m} 33.00 \\
-\mathrm{sg}\end{array}$ & $\begin{array}{c}\operatorname{TA} 100 \\
+S 9\end{array}$ \\
\hline \multirow{3}{*}{$\begin{array}{l}\text { 3,3'-aichlorobenziaine } \\
(D C B z)\end{array}$} & $z$ & 51 & 93 & 127 & 145 \\
\hline & 12 & $=22$ & 1,176 & 118 & 205 \\
\hline & $\Xi 0$ & 376 & 2,276 & 130 & 1,190 \\
\hline \multirow{3}{*}{$\begin{array}{l}\text { 3,3'-dichloro-N-acetylbenzidine } \\
(\text { S-ACDCSz) }\end{array}$} & 2 & $\therefore i$ & 57 & $224^{\circ}$ & 129 \\
\hline & 10 & $\approx 3$ & 924 & 122 & 211 \\
\hline & 50 & 22 & 4,230 & 224 & 376 \\
\hline \multirow{3}{*}{ 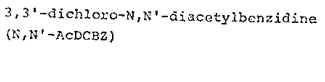 } & 2 & 23 & .114 & 319 & 228 \\
\hline & 20 & 20 & 511 & 127 & 171 \\
\hline & 50 & 2.3 & 517 & 232 & 183 \\
\hline $\cos t r c x^{b}$ & - & 25 & 23 & 120 & 220 \\
\hline
\end{tabular}

拉よび前記尿抽出物について, Salmonella typhimurium TA 98 和よび TA 100, PCB 誘尊による S9 mix, プレ インキュベーション法衫とよる Ames test を試みた。

\section{実験結果岕よび考察}

GC, HPLC 分析いずれの場合も箩 1 , 第 2 群尿抽出 物中に $\mathrm{DCBZ}$ と並んで N-AcDCBZ, NN'-AcDCBZ が みいだされた。第 3 群では， NN'-AcDCBZ はみいださ れたが DCBZ N-AcDCBZ は検出できなかった (Table 1).ラット尿の変黑原性は，個々のラット原抽出物责々 の尿量 $(\mathrm{ml})$ で除した dose level で his ${ }^{+}$revertant の增加がみられるかどうかの判定空行原い，これが認め

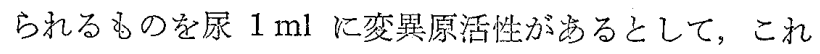
を有する 1 群中の個体数を Table 1 に示した. Table 2 K DCBZ, N-AcDCBZ, NN'-AcDCBZ ○ Ames test 結果を示した. Fig. 2 は DCBZ 乱よびその代謝物の変 異原性の強さを，BZ についてすで得られているわ和 われの成績と封比して示したものである.

BZ の代謝経路として Morton ${ }^{5)}$ は，BZ $\rightarrow \mathrm{N}$-acetylbenzidine $\rightarrow N$, $N^{\prime}$-diacetylbenzidine $\rightarrow N$-hydroxy-N, $N^{\prime}$-diacetylbenzidne $\rightarrow$ nucleic acid binding の変化が あることを証明している。本実験で DCBZ の代謝物と して N-AcDCBZ，NN'-AcDCBZ を同定し圥たことは， 両者に共通の代謝経路が西ることを推定させている。 


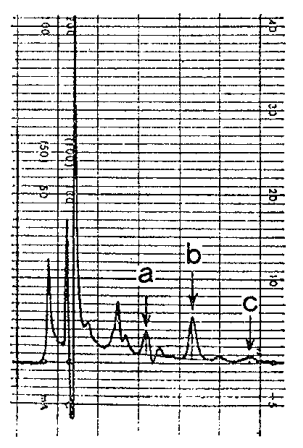

Fig. 1. Liquid chromatogram of urine extract of a rat to which 3, 3'-dichlorobenzidine (DCBZ) was orally given. a : $3,3^{\prime}$-dichloro-N, $N^{\prime}$ diacetylbenzidine (NN'AcDCBZ), b: 3, 3'dichloro-N-acetylbenzidine (NAcDCBZ), c : DCBZ. HPLC-Pump : Altex 110 A, Column : $30 \mathrm{~cm} \times 4 \mathrm{~mm}$ i.d. stainless column packed with M. Nagel Nucleosil $10 \mathrm{C}_{18}$, Injector : Rheodyne 7125, Detector : Shimadzu SPD-1 operated at $280 \mathrm{~nm}$, Column temperature : ambient, Mobile phase : 65\% methanol in water $\left(0.01 \mathrm{M} \mathrm{KH}_{2} \mathrm{PO}_{4}\right)$ at $1 \mathrm{ml} / \mathrm{min}$

Nアセチル代謝物の量は個体差が大きい. テット尿の 示す変異原活性はその中に含末れる代謝物の質量に影響 されるところが大きいと考えられる．第 3 群では $1 \mathrm{ml}$ の尿炕变異原活性が認められなかった。

代謝物变異原活性の強さについてみると， $\mathrm{NN}^{\prime}-\mathrm{Ac}$ DCBZ の変異原活性は DCBZ いちじるしく低下して拈り，Fig. 2 に示されるように， $\mathrm{N}, \mathrm{N}^{\prime}$-diacetylate Kも強い変異原活性のみられる $\mathrm{BZ}$ の場合とはきわめて対照的である. N, N'-diacetylateの 変異原活性が $\mathrm{N}$-acetylate に比し低下-る現象はオルト トリジンについてもわれわれによってみいだされてい る゙. これらはとトに対する発がん性がこ机ら BZ 誘導 体の場合には証明されていない7 といら票実と対応させ て考察した場合，一のの示唆をあたえるものと考えられ 万.

いずれにせよ $\mathrm{DCBZ}$ 投与ラット覀に投与ルートの別 なく代謝物を検出しえたことは，この物質の代謝や発が

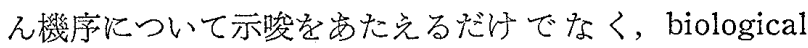
monitoring の手段としてもこれが利用できる可能性を 示したものといえよう。

\section{文献}

1) Sciarini, L. J. and Meigs, J. W. : Biotransformation of the benzidines. Studies of diorthotolidine,
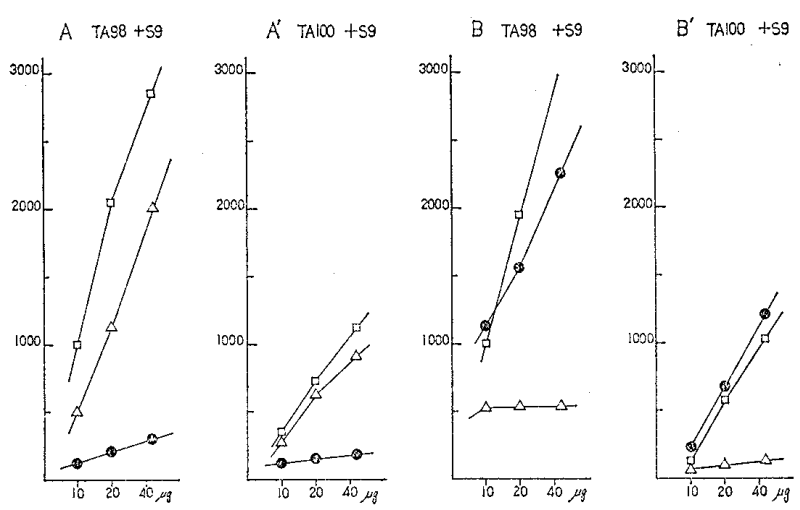

Fig. 2. Mutagenic activities of metabolites of 3, 3'-dichlorobenzidine (DCBZ) and benzidine $(\mathrm{BZ})$. (A) and $\left(\mathrm{A}^{\prime}\right)$ show mutagenic activities of $B Z$ and its metabolites, while (B) and $\left(\mathrm{B}^{\prime}\right)$ those of DCBZ and its metabolites. : parent substances, $\square:$ N-acetylates, $\triangle$ : N, N'diacetylates. Longitudinal axis shows histidinepositive revertants per plate.

dianisidine, and dichlorobenzidine : $3,3^{\prime}$-disubstituted congeners of benzidine (4, 4'-diaminobiphenyl), AMA Arch. Environ. Health, $2: 584-588,1961$.

2) Kellner, H. M., Christ, O.E. and Loetzsch, K.: Animal studies on the kinetics of benzidine and 3, 3'-dichlorobenzidine, Arch. Toxicol., 31:61-79, 1973.

3) Ames, B. N., McCann, J. and Yamasaki, E.: Methods for detecting carcinogens and mutagens with the Salmonella/mammalian-microsome mutagenicity test, Mutat. Res., 31 : 347-364, 1975.

4) Yahagi, T., Nagao, M., Seino, Y., Matsushima, T., Sugimura, T. and Okada, M.: Mutagenicities of N-nitrosamines on Salmonella, Mutat. Res., $48: 121-129,1977$.

5) Morton, K.C., King, C. M. and Baetcke, K. P.: Metabolism of benzidine to N-hydroxy-N, $\mathrm{N}^{\prime}$ diacetylbenzidine and subsequent nucleic acid binding and mutagenicity, Cancer Res., 39 : 31073113, 1979.

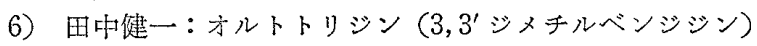
の尿中代謝物之その变異原性, 産業医学, $23: 168-169$, 1981.

7) Haley, T. J. : Benzidine revisited. A review of the literature and problems associated with the use of bezidine and its congeners, Clin. Toxicol., $8: 13-42,1975$.

\section{田的健一}

東 $\nu$ 滋賀病院

Ken-ichi TANAKA

Toray Shiga Hospital, 7-35, Sonoyama 2-chome, Otsu, 520 Japan

昭和56年 1 月 7 日受付

通信先: 田中专て, Reprint requests to $\mathrm{K}$. Tanaka 